\title{
Conflict management: challenges experienced by nurse-leaders in the hospital environment
}

\author{
Gerenciamento de conflitos: desafios vivenciados \\ pelos enfermeiros-líderes no ambiente hospitalar \\ Gestión de conflictos: desafíos vividos por los enfermeros-líderes \\ en el ambiente del hospitalario \\ Simone Coelho Amestoy ${ }^{a}$ \\ Vânia Marli Schubert Backes ${ }^{b}$ \\ Maira Buss Thofehrnc \\ Jussara Gue Martini ${ }^{d}$ \\ Betina Hörner Schlindwein Meirelles ${ }^{\mathrm{e}}$ \\ Letícia de Lima Trindade ${ }^{f}$
}

DOl: $\quad$ http://dx.doi.org/10.1590/19831447.2014.02.40155

Doctor of Nursing. Assistant Professor at the Nursing School of the Federal University of Pelotas - UFPel Pelotas (RS), Brazil. Member of the Nursing Studies and Research Center - NEPEN.

${ }^{b}$ Doctor of Nursing. Associate Professor II of the Postgraduate Program at the Federal University of Santa Catarina - UFSC - Florianópolis (SC), Brazil. Vicecoordinator of the Postgraduate Nursing Program at the UFSC. Leader of the Nursing and Health Education Research Group (EDEN). CNPq Researcher.

' Doctor of Nursing. Assistant Professor at the Nursing School of the Federal University of Pelotas. Leader of the NEPEN Research Group.

d Doctor of Nursing. Assistant Professor of the Nursing Department and Postgraduate Nursing Program at the UFSC. Member of the EDEN Research Group.

e Doctor of Nursing. Assistant Professor of the Nursing Department and Postgraduate Nursing Program at the UFSC. Member of the Study and Research Group in Administration and Management of Nursing and Health Care (GEPADES) and the Nursing and Health Care Study Center for People with Chronic Diseases (NUCRON).

' Doctor of Nursing. Assistant Professor at the State University of Santa Catarina-UDESC-Chapecó (SC), Brazil. Member of the UFSC Praxis Group and leader of the Health and Work Research Group (GESTRA) UDESC).

\section{ABSTRACT}

This study aimed to understand the main conflicts experienced by nurses-leaders in the hospital environment, as well as the strategies adopted to face them. The study reflects a qualitative descriptive type approach, which was used in the case study as research strategy. The study included 25 nurses who worked in three hospitals in the city of Florianopolis, Santa Catarina. Information where obtained in the months of May to December of 2010 through semi-structured interviews, non-participant observation and dialogical workshops. Data were analyzed using the Thematic Analysis. The results demonstrated the predominant of interpersonal conflicts involving the multidisciplinary team, nurses and the nursing staff. Adopting a participatory leadership, based on dialogue emerges as a strategy for coping with conflicts in the hospital environment.

Descriptors: Nursing. Leadership. Interpersonal relations.

\section{RESUMO}

Este estudo objetivou compreender os principais conflitos vivenciados pelos enfermeiros-líderes no ambiente hospitalar, bem como as estratégias adotadas para seu enfrentamento. A pesquisa retrata uma abordagem qualitativa do tipo descritiva, na qual foi usado o estudo de caso como estratégia de investigação. Participaram do estudo 25 enfermeiros que trabalhavam em três hospitais da cidade de Florianópolis, Santa Catarina. As informaç̧ões foram obtidas de maio a dezembro de 2010, por meio de entrevistas semiestruturadas, observação não participante e oficinas dialógicas. Os dados foram analisados conforme a Análise Temática. Os resultados apontaram o predomínio de conflitos de origem interpessoal envolvendo a equipe multiprofissional e também entre 0 enfermeiro e a equipe de enfermagem. A adoção de uma liderança participativa, baseada no diálogo, surge como estratégia para o enfrentamento dos conflitos no ambiente hospitalar.

Descritores: Enfermagem. Liderança. Relações interpessoais.

\section{RESUMEN}

Este estudio tuvo como objetivo comprender los principales conflictos vividos por los enfermeros-líderes en el hospital, así como las estrategias adoptadas para su enfrentamiento. La investigación retrata un abordaje cualitativo, de tipo descriptivo, en la cual se utilizó el estudio de caso como estrategia de investigación. Participaron del estudio 25 enfermeros que trabajaban en tres hospitales de la ciudad de Florianópolis, Santa Catarina. La recogida de datos fue de mayo a diciembre de 2010, por medio de entrevistas semiestructuradas, observación no participante y talleres dialógicos. Los datos fueron analizados conforme Análisis Temático. Los resultados señalaban el predominio de conflictos de origen interpersonal involucrando al equipo multiprofesional y también entre el enfermero y el personal de enfermería. La adopción de un liderazgo participativo, basada en el diálogo surge como estrategia para el enfrentamiento de los conflictos en el ambiente del hospital.

Descriptores: Enfermería. Liderazgo. Relaciones interpersonales. 


\section{口INTRODUCTION}

Education in nursing in the country has been facing transformations over the years in order to meet the demands generated by the complexity of the care, models of care, technological advancements and changes to the demographic and epidemiological profile of the population, causing changes in academic training ${ }^{(1)}$.

It is worth remembering that in 2001, the new Curricular Guidelines for Nursing Undergraduate Courses were established ", with the nursing students having to cover the following competencies: working in healthcare, decision making, communication, administration and management, permanent education and leadership ${ }^{(2)}$.

In the current context, leadership represents a reality permeating all of the nurse's actions owing to the frequent occupation of management position in health services ${ }^{(3)}$. The mastery of managerial competencies contributes to the activities of such professionals in these new areas through the application of administrative, technical and relational knowledge ${ }^{(4)}$. This is also due to changes in the healthcare model that seeks to distance itself from the hegemonic medical model and vertical power relationships, opening up space for new ways of doing health and for the strengthening and credibility of the actions of nurses.

Added to this is the fact that in the hospital environment, nurses acting as managers needs to be prepared to assume the role of leader, representing a basic condition for achieving transformations in the job, reconciling the targets of the organization and the priorities of the nursing team ${ }^{(5)}$. As such, leadership is understood as the ability of the nurse-leader to influence their team, aimed at achieving objectives shared by the group, with the main purpose of meeting the health needs of the patients and their families.

However, in some situations, the person influenced ends up not recognizing the power exercised by the influencing agent or opposes them, acting contrary to that expected by the agent, generating tensions and conflicts in the work environment ${ }^{(6)}$. For this reason, the nurse-leader should develop skills that include the capacity to see the whole, incentivize creative thinking in the team, sensible decision making, synthesizing points of view, identify and resolving conflicts $^{(7)}$.

Given the multiple activities attributed to nurses, management of the care and the team, there is a need to manage the practical conflicts inherent in the nurse's work process. This skill is also required when analyzing the work of nurses in the field of health, which is for the most part carried out as collective work ${ }^{(8)}$, with necessary contact with professionals from other areas. Faced with this perspective, it becomes relevant to investigate conflict relationships, as these, in turn, emerge from the distancing between the actions and discourse of nurses and the multi-professional team.

Conflict may be considered as a break in order, a negative experience caused by error or failure As such, conflict management consists in the way of dealing with these problems, which may be overcome using four strategies: accommodation, which consists in covering up problems; domination, when the strongest party imposes their preferred solution; bargaining, where each party gives in a little, and the integrative solution of conflicts, with the purposes of satisfying the needs of both parties by seeking alternative solutions ${ }^{(9)}$.

It therefore becomes relevant within nursing to construct new management methods that include knowledge of health policies and their operationalization, as well as improving leadership skills and abilities capable of contributing to more dialogical and integrative practices in which conflicts cannot be omitted ${ }^{(10)}$.

Given the above, the question that guided this study emerges: what are the main conflicts experienced by nurse-leaders in the hospital environment, as well as the strategies adopted for dealing with such? Based on this, the aim was to understand the main conflicts experienced by nurse-leaders in hospital environment, as well as the strategies adopted for dealing with them.

\section{口 METHODOLOGY}

This is a qualitative study in which case studies were used as an investigational strategy, as a method applied in situations where a single phenomenon with its own value is being studied ${ }^{(11)}$. A multiple case stud was chosen in order to reveal the multiple dimensions present in the subject under study, focusing on this in its totality. This type of approach emphasizes the natural complexity of the situations, demonstrating the interrelation of its components ${ }^{(11)}$.

The study was composed of 25 nurses working at three prominent hospitals in the city of Florianopolis, Santa Catarina. The number of participants was established by progressive inclusion until reaching the criteria for data saturation. The inclusion criteria for the participants were: being a nurse; having at least six years of training, under the New Curricular Guidelines for Nursing Undergraduate Courses, and being in contact with the work team. Nurses that exceeded this training time, were absent for any rea- 
son (annual leave, maternity leave or illness) and nurses carrying out activities without contact with the work team were excluded.

Semi-structured interviews, nonparticipant observation and dialogical workshops were used to collect data. The interviews were undertaken in the work environment of the participants in an individual manner, at a pre-established date and time, as per prior contact. The interviews were recorded and transcribed at the end. The testimony of each participant was identified by the letter $E$ for interview and an ordinal number corresponding to its realization with the nurses (E1, E2... E25).

Nonparticipant observation was the second technique for data collection. An average of four hours in the work routine of each participant was observed, totaling 100 hours. The observations were identified by the letter $O$ for observation followed by an ordinal number corresponding to each nurse $(\mathrm{O} 1, \mathrm{O} 2 \ldots . \mathrm{O} 25)$.

After the observations, three workshops were conducted, one at each hospital, so that the participants could construct and reconstruct there point of view on the issue collectively. The nurses participated at workshops held at the hospitals where they worked. Each dialogical workshop lasted an average of 1 hour and 30 minutes, The testimonies derived from the dialogical workshops were identified with the letters OD plus the ordinal number representing each nurse (OD1, OD2...OD25). One of the researchers exercised the role of moderator for the meetings. The information was obtained from May to December 2010.

Thematic Analysis was used with the intention of analyzing the data ${ }^{(12)}$. The ethical principles established by the Ministry of Health's National Health Council Resolution 196/96, with the approval of the Research Ethics Committee at the Federal University of Santa Catarina, under Registration $n^{\circ} 658 / 10$.

\section{RESULTS AND DISCUSSION}

When analyzing the results obtained, it was identified that conflicts originating from interpersonal relationships were predominant. Thus, owing to their magnitude, two categories emerged: management of interpersonal conflicts and strategies for dealing with interpersonal conflicts.

\section{Management of interpersonal conflicts}

Problems in interpersonal relations were characterized as situations which made the nurse's leadership performance most difficult in the hospital environment, as shown in the statements below:
My greatest difficulty is dealing with conflict, seeing employees arguing with each other, not speaking or not collaborating, and then you have to call this to their attention, which I think is the worst part (E15).

[...]it's complicated when the relationship is not good. I always say to them that nobody is obliged to love anybody here, but we have to respect each other (E21).

One of the shifts is more complicated because there are people with strong personalities that do not accept opinions and criticism. So, it can be quite taxing (E25).

[...] it's complicated, because you can't make everyone happy, there will always be one person that's not content (OD2).

Interpersonal conflicts are those that have a relational nature, and may occur between people, between a group and a person, between an organization and a group, and so on ${ }^{(9)}$. Furthermore, interpersonal relationships are considered as a potential stressor, as they involve various individual and group variables, making it unfeasible to find a measure capable of making everyone happy ${ }^{(6)}$.

Given the complexity of healthcare work, conflicts also arise between various professionals. Misunderstandings between nurses and physicians are common in hospital environment. Interpersonal conflicts among these professionals tend to interfere in the progress of health work and consequently the performance and motivation of these workers, affecting the quality of the care to users. The participants'statements affirm these conflicts:

Nurses waste a lot of time arranging medical records and requests for exams and often stated they feel like secretaries of the physicians, as these professionals ask them for everything in terms of paperwork (O6).

I cared for a patient with tracheostomy complications [...] the physician was very angry and start to shout and argue with everyone. It's very complicated working with people sometimes, it makes you want to run off (E7).

[...] there's a lot of that here, the physicians here like to dominate, if you let them they'll dominate, they want to give orders and shout (E16).

The conflict instated between physician and nurse can be one of the main problems in health services. This conflict causes ethical problems that end up negatively affecting the relationship, prejudicing the care provided 
to the patient. As such, it is necessary to allocate efforts so that these problems can be avoided or minimized ${ }^{(13)}$. It was noted that the organization of the work of health professionals in the hospital environment is permeated by greater valorization and dominance by physicians meaning that nurses are often led to solving problems outside of their scope.

In relation to the history of the organization of health professionals, there has been an institutionalization process centered on medicine as the legal holder of knowledge. Even with the relativity of medical control over such professionals, physicians still continue to hold legal power of healthcare. It is worth emphasizing that part of the conflict that occurs in organizations is derived from unequal distribution of power, requiring greater comprehension and negotiation from managers in order to resolve them ${ }^{(14)}$. However, the physician-nurse relationship may generate conflicts that often concealed and presented as a discreet dispute for power, in which both which to confirm their role in the treatment of patients, i.e. who prescribes and who administers the medication ${ }^{(15)}$.

A study has revealed that in the nursing area, when a worker witnesses a physician acting outside of their routine, they proceed in accordance with their hierarchical position. Therefore, a nursing technician will general allow the physician to act as they wish and subsequently inform the situation experienced to their supervisors. Frequently, nurses experiencing a problem will take action if the physician maintains their previous conduct, and will tend to take the problem to superior authorities ${ }^{(14)}$. This result is seen as an advance given that nurses often adopt a position of conformism faced with routines and contractions of hospital activities resulting from the power relationship ${ }^{(15)}$.

Conflicts involving the multi-professional team, especially physicians, represent a challenge for nurses. Thus, the cause of these conflicts should be uncovered in order to find solutions and strategies for dealing with them, as environments where conflicts are not handled interfere in performance, professional motivation and affect the quality of the care.

Lack of commitment by team members in relation to certain activities and prejudicing the continuity of the care and discomfort between workers was also experienced by participants in the study. The following statement shows this kind of conflict:

When the shift was handed over, the nurse became aware that one patient hadn't been prepped for surgery. The nurse called an employee and told her, and she angry with the situation, saying that the obligation for giving the patient a bath was for the night shift. After stating her opinion, the nursing technician went to help the patient to bathe (O6).

Conflicts between professionals in the nursing team are prominent for a large part of nurses. There is a lot of evidence that these professionals are divided between legalism and basic needs, emotion and applicability of standards, and ethical dilemmas and remaining in their position ${ }^{(10)}$. These conflicts may be clearly expressed, represented by the increased in criticisms, implications or discussions between team members. On the other side, when not openly demonstrated, conflict may cause demotivation and dissatisfaction in the team, affecting the quality of the work ${ }^{(16)}$, as well as suffering for the worker.

Difficulty for workers in providing continuity to team actions that came before them also emerged in the study as a problem in the hospital environment. Leaving an activity for another time is frequent and seen as a lack of commitment and responsibility, neglecting the progress of nursing activities and consequently the care provided. This problem is faced by the nurse-leader.

Conflict implies disorganization of all team members and causes incased stress owing to the lack of participation in decision making, lack of management support, overwork, and rapid technological changes. Furthermore, other factors collaborate to causing conflicts, including high turnover of professionals, disrespect for workers, lack of trust and professional devaluation ${ }^{(16)}$. The issue of turnover is illustrated in the following statements:

The turnover doesn't help because you can't create a connection. I think it really doesn't help structurally, so it's negative for us (E11).

We see a large turnover on the technical level, with people staying one, two or three weeks, but they can't cope, because there're a lot of demands (E19).

There's a high turnover, we see it as the institution's fault because a lot of people leave the hospital because they're unhappy. A lot of people take the entrance exam, pass and then leave (E23).

Four people were off on Saturday, so I had to fill in using people from the general on call shift [...] I know it's horrible, nobody wants to leave their wing. There was rotation before but it had to be stopped (OD10).

The intense turnover of professionals at the units is understood as a prejudicial aspect that interferes in the qual- 
ity of the care ${ }^{(17)}$, as constant rearrangement of professionals prevents the formation of professional ties and building teamwork based on union and the establishment of clear and common objectives.

Another relevant result was being overloaded with work, which was also indicated as generating conflicts:

[...] if employees had less patients the quality would be higher (E8).

At present, being overloaded with work is a big challenge we're experiencing, as we have few employees. This has been very difficult (E12).

It is very difficult to be overworked, you end up saying: I'm going to run away, but I can't abandon my patients and my employees (E14).

[...] the weakness / find by being overworked is very strong, it's a very stressful routine and a large and complex ward (E22).

The issue of being overworked as experienced by the participants in the study may directly interfere in the satisfaction of the worker and consequently generate conflicts, affecting leadership and interfering in the care. Being overworked also usually causes fatigue and exhaustion in the professional and can lead to extreme situations such as mistreatment of the patient, an important problem in healthcare management.

I had problems with a nighttime employee that was very rude to patients. The patients complained every day. I wasn't extreme with him, as that's not my style, but I went to the management and ended up removing him from the sector (E5).

[...] sometimes employees mistreat a patient, they person has two or three jobs and comes here too, and they can't manage it all so they end up taking it out on someone, such as the patient (E17).

When witnessing this type of situation, the nurse cannot hesitate to take a stance or choose to take ownership of the situation, i.e. not expecting the team to resolve the problem. From the moment that care is neglected and the human being is exposed to risks it is indispensable that the nurse, as the legal person responsible for coordinating the actions by the nursing team reprehends the behavior and, if necessary, notifies the situation to their superiors.

\section{Strategies for dealing with interpersonal conflicts}

In relation to conflict management, some strategies have arisen that promote a better routing for solving them, including nurses adhering to a participatory and dialogical leadership style.

[...] very participative, very democratic leadership where I think that people in the team are able to achieve the best healthcare possible for the patient (E9).

I try to exercise this leadership in a participative manner. I remain very open because we are here to work for the patient's benefit (E13).

[...] I try to listen to others so that we can reach a conclusion on what's best to do together. So, my leadership is very participative (E20).

[...] everything requires conversation, and not imposing a situation without knowing what the team thinks, without the participation and consensus of all (E24).

The leadership style consists in the behavior adopted by the leader in order to influence their collaborators, which may be authoritarian, based on the use of power, or democratic, in which people have greater freedom to participate in decision making. The literature shows that the democratic style is closes to authentic leadership, which involves all members of the team not only in decision making processes but in the elaboration and planning of strategies for work and problem solving. Authentic leadership is centered on communication as an instrument to achieve the best results in health ${ }^{(18)}$.

Participation emerges as an instrument that collaborates with cooperation and conflict solving. When admitting that conflict has an origin in organizational and individual factors, it is believed that the use of participative methods is an effective solution, as well as accommodation or equilibrium between people and divergent groups $^{(14)}$.

Authors mention listening, respect and dialog as strategies for dealing with conflicts that is, as a springboard for getting out of a problematic situation as a possibility for resolution ${ }^{(15)}$. This was shown in the participants" dialogs:

[...] I talk a lot with them. I've never needed more abrasive conduct and have always managed to resolve things by talking (E1). 
I try to speak with the personnel a lot. I don't like to impose things, because I don't like them imposing anything on me (E3).

I always like to be more democratic, to talk and have dialog. I do not come with a closed mind; it doesn't need to be like that I think (E4).

[...] I've always been available to talk and discuss issues with the whole team so they feel at ease and can bring up problems for me to try and help resolve (E18).

For there to be participation it is necessary for dialogical interpersonal relations to flourish in the work environment. This means a new proposal for leadership, denominated dialogical leadership, which is based on establishing a horizontal communication process with the intention of potentiating autonomy, responsibility and valorization of team members and health service users, as well as helping in decision making, planning and implementation of care practices ${ }^{(19-20)}$.

By stimulating relationships based on dialog, it is believed that nurses can manage conflicts arising in the work environment in a more coherent manner. This dialog, which is different from empty conversation, values the prior knowledge of the participants as historical and social beings, which can awaken people's capacity to become a political actor, i.e. a professional that defends their convictions, is ready to act, has coherence between what they do and what they say, and is a reference point at the units, as well as in the health service.

\section{GINAL CONSIDERATIONS}

After undertaking this study the main conflicts experienced by nurse-leaders working in the hospital environment could be understood. The most prominent challenges faced by nurses are interpersonal conflicts involving some members of the multi-professional team owing to the power relationships in the health area.

Interpersonal conflicts between the nurse and the nursing team were identified as interfering in the continuity of the care. It was reinforced that collectivity is the essence of the care given by nurses, and without this understanding people replicate individualistic, fragmented and alienating practices. In this context, the nurse is responsible for avoiding the reproduction of negative conduct, given that their legal duty is to coordinate the activities carried out by the nursing team. Furthermore, these problems result in inappropriate positions and even negligence in relation to patient care.
The study indicated that certain strategies can contribute to conflict management, including dialogical leadership. As a case study, the results cannot be generalized, however, other institutions and professionals also face similar situations. For this reason, the importance of presenting these results in the scientific community and population in general can be defended.

The limitations of the study include the collection of data, where it was not possible to bring together all of the nurses in a dialogical workshops owing to lack of availability, given that some have other employment relationships and others works eight hours per day, preventing the meetings from being conducted. The dialogical workshop counting on the participation of nurses from the three scenarios contributed to a more open and conscientious discussion about conflict management.

It is hoped that the issue will be covered in more depth by instructors during the training process for new nurse-leaders, in order for them to develop relational skills that contribute to their safety and professional competency in dealing with conflict situations.

\section{口EFERENCES}

1. Erdmann AL, Fernandes ID, Teixeira GA. Panorama da educação em enfermagem no Brasil: graduação e pós-graduação. Enferm Foco. 2011;2(supl):89-93.

2. Ministério da Educação (BR), Conselho Nacional de Educação. Resolução 3, de 07 de novembro de 2001: diretrizes curriculares nacionais do curso de graduação em enfermagem. Braślia (DF); 2001. p. 37.

3. Amestoy SC, Backes VMS, Trindade LL, Canever BP. Produção científica sobre liderança no contexto da enfermagem. Rev Esc Enferm USP. 2012;46(1):227-33.

4. Motta KAMB, Munari DB, Costa FN. Os pontos críticos das atividades do enfermeiro gestor no hospital público. REPSPP [Internet]. 2009 [citado 2014 jan 20]; (1):73-99. Disponível em: http://www.crp09.org.br/NetManager/documentos/v1n1a5.pdf

5. Cardoso MLAP, Ramos LH, D'Innocenzo M. Liderança coaching: um modelo de referência para o exercício do enfermeiro-líder no contexto hospitalar. Rev Esc Enferm USP. 2011;45(3):730-7.

6. Costa DT, Martins MCF. Estresse em profissionais de enfermagem: impacto do conflito no grupo e do poder médico. Rev Esc Enferm USP. 2011;45(5):1191-8.

7. Girard N. Educational leadership in professional nursing. Perioper Nurs Clin. 2009;4(1): 43-9.

8. Pires DEP. Transformações necessárias para o avanço da enfermagem como ciência do cuidar. Rev Bras Enferm. 2013;66(nesp):39-44.

9. Kurgant, P. Gerenciamento em enfermagem. Rio de Janeiro: Guanabara Koogan; 2012. $196 \mathrm{p}$.

10. Guerra ST, Prochnow AG, Trevizan MA, Guido LA. 0 conflito no exercício gerencial do enfermeiro no âmbito hospitalar. Rev Lat-Am Enfermagem. 2011;19(2):362-9.

11. Lüdke $M$, André MEDA. Pesquisa em educação: abordagens qualitativas. São Paulo: EPU; $1986.99 \mathrm{p}$.

12. Minayo MCS. 0 desafio do conhecimento: pesquisa qualitativa em saúde. 12. ed. São Paulo: Hucitec; 2010. 407 p. 
13. Oliveira AM, Lemes AM, Machado CR, Silva FL, Miranda FS. Relação entre enfermeiros e médicos em hospital escola: a perspectiva dos médicos. Rev Bras Saúde Matern Infant. 2010;10(supl. 2):\$433-9.

14. Vendemiatti M, Siqueira ES, Filardi F, Binotto E, Simioni FJ. Conflito na gestão hospitalar: o papel da liderança. Cienc Saúde Colet. 2010;15(supl.1):130114.

15. Prochnow AG, Leite JL, Erdmann AL, Trevizan MA. 0 conflito como realidade e desafio cultura no exercício da gerência do enfermeiro. Rev Esc Enferm USP. 2007;41(4):542-50.

16. Sales, AAR, Lima FRF, Farias FSAB. Refletindo sobre a administração e negociação de conflitos nas equipes de saúde. RBPS. 2007;20(2):111-5.

\section{Author's address:}

Simone Coelho Amestoy

Rua Gomes Carneiro, 1, Porto

96010-610, Pelotas, RS

E-mail: simoneamestoy@hotmail.com
17. Amestoy SC, Cestari ME, Thofehrn MB, Milbrath VM, Porto AR. Características institucionais que interferem na liderança do enfermeiro. Rev Gaúcha Enferm. 2009;30(2):214-20.

18. Lanzoni GMM, Meirelles BHS. Leadership of the nurse: an integrative literature review. Rev Latino-Am Enfermagem. 2011;19(3):651-8.

19. Amestoy SC, Trindade LL, Waterkemper R, Heidman ITS, Boehs AE, Backes VMS. Liderança dialógica nas instituições hospitalares. Rev Bras Enferm. 2010;63(5):844-7.

20. Amestoy SC. Liderança dialógica: perspectivas na formação de enfermeiros-líderes [tese]. Florianopolis (SC): Programa de Pós-Graduação em Enfermagem, Universidade Federal de Santa Catarina; 2012.
Received: 27.05.2013

Approved: 17.03.2014 